MILENA BUĆ Instytut Politologii UMK

\title{
DETERMINANTY \\ AKTYWNOŚCI POLITYCZNEJ WYBORCÓW
}

\author{
„Zagwarantowane konstytucyjnie instytucje i wolności \\ są tyle warte, ile potrafi z nich wydobyć \\ nawykła do perspektywy $m y$, \\ przyzwyczajona do praktyki samookreślania się ludność”. \\ Jürgen Habermas
}

Wolne wybory uznawane są za istotę i podstawę systemu demokratycznego. Zwycięstwo w głosowaniu powszechnym jest jedyną, akceptowaną w „cywilizowanym świecie”, droga do zdobycia i legitymizacji władzy. Bardzo ważne zatem jest, aby władza była zdobyta i prowadzona zgodnie $\mathrm{z}$ określonymi regułami. Szczególne zainteresowanie wszystkich uczestników życia publicznego skupia się jednak nie na wyborach, lecz wyborcach. Zachowania wyborcze, będące przedmiotem niniejszej analizy, można interpretować na dwa sposoby. Po pierwsze jest to konwencjonalna forma aktywności politycznej, rozumianej jako „aktywne wsparcie politycznej ciagłości lub zmiany” Jest to więc udział w wyborach lub absencja wyborcza. Po drugie, sa to konkretne preferencje elektoratu, które decydują o wyniku wyborów. Motywy obu tych zachowań przenikaja się, w związku z czym rzetelna analiza zjawiska wymaga spojrzenia całościowego. Punktem wyjścia do powyższych rozważań będzie rys teoretyczny, poparty dorobkiem amerykańskich naukowców, skonfrontowany z badaniami przeprowadzonymi w Polsce po 1989 r.

${ }^{1} \mathrm{~K}$. Korzeniowski, Psychologiczne uwarunkowania zachowań myborczych, w: Podstawy psychologii politycそnej, pod red. Krystyny Skarżyńskiej, Zysk i S-ka, Poznań 2002, s. 237-238. 


\section{Dlaczego wyborcy głosują?}

Istnieje wiele modeli teoretycznych próbujących wyjaśnić motywy zachowań wyborczych. Pierwszych znaczących analiz dokonał w latach 50. A. Downs. W stworzonym przez niego modelu wyborca ukazany zostaje jako istota racjonalna. Dokonując bilansu zysków i strat odpowiada sobie na pytanie: Czy udział w wyborach mi się opłaca? Wyborca zdecyduje się głosować tylko wówczas, jeżeli odpowiedź okaże się twierdząca. Dokonanie kalkulacji opiera się o następujące zmienne: koszty głosowania; prawdopodobieństwo, że przez głosowanie uda się wywrzeć wpływ na wynik wyborów oraz przeświadczenie, że wygrana danego kandydata przyniesie jednostce korzyści. Kategorie kosztów i zysków (materialnych, poznawczych i emocjonalnych) brane pod uwage przez jednostkę są bardzo szerokie ${ }^{2}$. Jeżeli więc koszty głosowania będa większe od zysków i oczekiwanego prawdopodobieństwa wywarcia wpływu na wynik wyborów wówczas wystapi wysoka absencja wyborcza. Modyfikacji klasycznego modelu racjonalnego wyborcy dokonał G. Tullock. Odwołując się to teorii Downsa stwierdził, że wpływ pojedynczego wyborcy na wynik wyborów jest niewielki, w związku z czym koszty będą zawsze przewyższać zyski. Stąd wniosek Tullocka, iż wyborcy sa istotami irracjonalnymi. W latach 60. W. H. Riker i P. Ordeshook wprowadzili do modelu racjonalnego wyborcy pojęcie „obywatelskiego obowiązku”. Zgodnie z ich koncepcja wyborcy w swych kalkulacjach biora także pod uwagę kwestię

\footnotetext{
${ }^{2}$ Kosztem materialnym jest fizyczny wysiłek, jaki należy włożyć w akt głosowania, czyli zarejestrować się na liście wyborczej (np. USA) czy udać do lokalu wyborczego. Za zysk materialny uznać można możliwość polepszenia sytuacji materialnej danej osoby lub grupy w wyniku wygrania wyborów przez partię, której program zakłada rozwiązania sprzyjające korzystnej zmianie (obniżenie podatków, pomoc socjalna, wspieranie przedsiębiorczości, itp.). Kosztem poznawczym będzie konieczność zainteresowania się kampanią wyborcza, zaznajomienie z programami partii i kandydatów oraz rozumienie sytuacji politycznej. Koszt ten wzrasta, gdy sytuacja na scenie politycznej jest niejasna, ordynacja wyborcza niezrozumiała dla obywateli a kandydatów bardzo wielu. Z kolei za zysk poznawczy uznać można przeświadczenie, że jeżeli głos oddany zostanie na kandydata lub partię, której poglądy podzielamy, urzeczywistniona zostanie nasza wizja rzeczywistości. Jeżeli natomiast wśród istniejących opcji nie znajdziemy takiej, która odzwierciedlałaby nasze poglądy, wówczas zagłosujemy dokonując wyboru mniejszego zła lub nie zagłosujemy wcale. Związany z tym „kac moralny”, jaki towarzyszył na przykład tym, którzy w 1990 r. głosowali na Wałęsę tylko po to, żeby nie głosować na Tymińskiego, był kosztem emocjonalnym. Zyskiem w tym wymiarze jest uniknięcie negatywnych emocji związanych z niewypełnieniem obywatelskiego obowiązku. Por. Tamże, s. 242-243.
} 
podtrzymania demokracji, subiektywnie rozumianego obowiązku względem państwa, narodu ${ }^{3}$.

W świetle opisanych powyżej modeli akt głosowania jawi się z jednej strony jako zachowanie instrumentalne, którego celem jest osiąnięcie korzyści lub uniknięcie strat, z drugiej zaś sam akt głosowania można odczytywać jako wartość samą w sobie. Dodatkowo, pomimo częstego przewyższania zysków przez koszty, wyborcy i tak głosują. Zdaniem K. Korzeniowskiego, przedstawione teorie z pewnością można stosować do wyjaśniania ex post, natomiast w stosunku do przyszłych wydarzeń ich wyniki mogą okazać się mało precyzyjne $e^{4}$.

Obszerną analizę zachowań wyborczych odnajdujemy także w Homo politicus S. M. Lipseta. Zdaniem autora, głównymi determinantami wysokiej frekwencji wyborczej w danej grupie są: duży wpływ polityki rządu na jej interesy, dostępność do informacji na temat związku decyzji politycznych $z$ interesami grupy, presja społeczna mobilizująca do oddania głosu oraz brak lub niewielka ilość krzyżujących się nacisków ${ }^{5}$. Zachowania wyborców są więc wypadkową wyżej wymienionych czynników. Na podstawie informacji na temat ich intensywności i charakteru można wyróżnić grupy społeczne, które cechuje wysoka absencja oraz takie, które biora udział w wyborach regularnie.

Wyborcy, na których polityka państwa wywiera bezpośredni, duży wpływ (np. urzędnicy państwowi, rolnicy indywidualni czy przedsiębiorcy) zdaniem Lipseta zazwyczaj uczestniczą w wyborach. Gdy w kampanii wyborczej poruszane są kwestie związane $z$ moralnością i szeroko rozumianymi wartościami religijnymi mobilizują się osoby wierzące i kobiety, które nadal częściej zwracają uwagę na problemy dotyczące kondycji moralnej społeczeństwa niż mężczyźni. Cechą charakterystyczną wszystkich grup społecznych, jak i społeczeństw w ogóle, jest wzrost zainteresowania polityką w okresach kryzysów politycznych, gospodarczych czy światopoglądowych. W Niemczech i Austrii najwyższa frekwencję zaobserwowano w latach 1932-1933, czyli podczas ostatnich wyborów przed upadkiem systemu demokratycznego ${ }^{6}$. Chęć wprowadzenia zmian lub utrzymania istniejącego porządku motywuje obywateli do działania. W USA wzrasta zainteresowanie wyborami, gdy wśród kandydatów pojawiają się „nowe twarze” lub przedstawiciele grup etnicznych, które do tej pory nie piastowały takich

\footnotetext{
3 Tamże, s. 241-242.

4 Tamże, s. 243. Por. też A. Malewski, O nowy ksztatt nauk spotecznych. Pisma zebrane, PWN, Warszawa 1975.

5 S. M. Lipset, Homo politicus. Spoteczne podstawy polityki, PWN, Warszawa 1995, s. 197.

${ }^{6}$ Tamże, s. 198-202.
} 
urzędów. W Polsce i innych krajach byłego bloku wschodniego (wyjątek stanowi była Czechosłowacja) najwyższa frekwencję zarejestrowano w okresie załamywania się starego porządku? ${ }^{7}$.

Dostęp do informacji to kolejny ważny czynnik wpływający na frekwencję wyborczą. Częściej głosują osoby należące do różnego rodzaju grup niepolitycznych, związków zawodowych, zrzeszeń, stowarzyszeń, wspólnot religijnych. Charakteryzują się one wysokim wskaźnikiem interakcji z ludźmi o podobnych problemach, pochodzeniu i poglądach. Zainteresowanie wyborami wynika $z$ faktu, iż w grupach mają oni możliwość dyskusji, artykulacji potrzeb, wymiany informacji i pogłębiania świadomości politycznej. Przykładem wpływu wspólnoty religijnej na partycypacje polityczną jest działalność Radia Maryja. Niska absencja występuje także wśród osób dobrze wykształconych charakteryzują się one wysoką kulturą polityczną, łatwiejszym dostępem do informacji oraz większymi umiejętnościami w ich zdobywaniu. Badania polskich naukowców prowadzone od 1989 r. wykazały, że także rodzice osób głosujących są lepiej wykształceni niż rodzice osób nie głosujących ${ }^{8}$.

$\mathrm{Na}$ charakter partycypacji politycznej duży wpływ ma też nacisk grupy, w jakiej dana jednostka się znajduje. Warianty zachowań wyborczych w dużej mierze wynikaja z konformizmu wobec dominujących w społeczeństwie norm zachowania. Istnieje wiele grup interesu, które domagają się, aby ich członkowie głosowali (np. związki zawodowe) lub wręcz przeciwnie (np. Anarcho-Syndykalistyczna Narodowa Konferencja Robotników w Hiszpanii w latach trzydziestych). Konformistycznie nastawione do życia są zwłaszcza osoby pochodzące z klasy średniej ${ }^{9}$. Największa społeczna kontrola występuje w małych miejscowościach. Osoby, które maja słaby kontakt ze społeczeństwem (np. nowo przybyłe do danej społeczności czy grupy) głosują rzadziej, gdyż wywierana na nich presja, aby głosować, jest niewielka. Specyficzny rodzaj nacisku występuje w państwach totalitarnych, gdzie udział w wyborach wynika $\mathrm{z}$ obawy przed sankcjami, ma wiec charakter pokazowy.

\footnotetext{
${ }^{7}$ K. Skarżyńska, Aktywność i bierność polityczna, w: Podstawy psychologii politycznej, dz. cyt., s. 44.

8 Tamże, s. 47-49. Por. R. A. Teixeira, Znikajacy wyborca w Ameryce, w: Władza $i$ społeczeństwo, pod red. Jerzego Szczupaczyńskiego, Scholar, t. 2, Warszawa 1998, s. $277-$ 283.

${ }^{9}$ Por. R. K. Merton, Struktura spoteczna i anomia, w: Tenże, Teoria socjologiczna i struktura spoteczna, PWN, Warszawa 1982, s. 195-223.
} 
Jednak im więcej nacisków działających na jednostkę z różnych stron, tym większe prawdopodobieństwo, że będzie się ona wycofywać z aktywnego udziału w życiu społecznym ${ }^{10}$. Krzyżujące się interesy, sprzeczne informacje docierające do potencjalnego wyborcy wpływają na wzrost kosztów poznawczych, a w konsekwencji tego niską frekwencję. Współczesność charakteryzuje się zwiększeniem ilości docierających do wyborców informacji. Za pośrednictwem mediów następuje „psychologiczne przytłoczenie człowieka” ${ }^{11}$. Zjawisko dysonansu poznawczego występuje zazwyczaj u osób mobilnych zawodowo, dążących do poprawy swojego statusu, często zmieniających miejsce zamieszkania. Wynika to $\mathrm{z}$ faktu, iż z jednej strony utożsamiają się z normami akceptowanymi przez środowisko, w którym żyja, z drugiej strony zaś, z normami społeczności, grupy zawodowej, do której chca wejść. Rzadziej głosuja też osoby młode, co wynika z faktu, iż są one bardziej mobilne przestrzennie i zawodowo, bardziej podatne na wpływ opinii ,innych”, oraz mniej zainteresowane polityką.

$\mathrm{Na}$ partycypację polityczną ogromny wpływ ma też specyfika sytuacji przedwyborczej (zarówno politycznej jak i społecznej) oraz osobiste dążenia jednostek. Frekwencja wyborcza jest wysoka, gdy wyborca uznaje sam akt głosowania za ważne wydarzenie, oddanie głosu stanowi pewną wartość, cel sam w sobie. Poziom zainteresowania wyborami zależy także od rodzaju wyborów, charakteru i wagi urzędu, o który walczą kandydaci. Większym zainteresowaniem cieszą się wybory prezydenckie niż parlamentarne. Wiązać to należy z faktem, iż kampanie prezydenckie mają zazwyczaj większy rozmach (zwłaszcza w USA), kandydatów jest niewielu w porównaniu z wyborami parlamentarnymi, przez co są bardziej wyraziści i rozpoznawalni. Dodatkowo, obywatele przywiązuja większe znaczenie do funkcji głowy państwa niż członka parlamentu. W wyborach prezydenckich w Polsce w latach 1995, 2000 i 2005 frekwencja była średnio o 10\% wyższa w stosunku do wyborów parlamentarnych $^{12}$. Jeżeli wyborcy maja natomiast przeświadczenie, że stanowiska, o które starają się kandydaci są mało ważne, a osoby do tej pory pełniące te funkcje nie cieszą się autorytetem, ich zainteresowanie wyborami będzie niewielkie. Taka sytuacja miała miejsce w wyborach

\footnotetext{
${ }^{10}$ S. M. Lipset, dz. cyt., s. 217-230.

11 T. Goban-Klas, Cywilizacja medialna. Geneza, ewolucja, eksplozja, WSiP, Warszawa 2005, s. 253.

${ }^{12}$ Por. K. Skarżyńska, dz. cyt., s. 43; Komunikaty Państwowej Komisji Wyborczej, http://www.wybory2005.pkw.gov.pl/SJM/PL/WYN/F/index.htm, http:/ / www.prezydent2005.pkw.gov.pl/PZT1/PL/WYN/F/index.htm, 14.11.2006.
} 
parlamentarnych w Polsce w 1991 i 1997 r. oraz w wyborach do Parlamentu Europejskiego w roku 2004.

$\mathrm{Na}$ udział w wyborach duży wpływ ma też miejsce zamieszkania, zarówno ze względu na zróżnicowanie sytuacji ekonomicznej poszczególnych regionów jak i tradycję. Zgodnie z hipotezą zaborową wyróżnić można w Polsce 4 regiony historyczne, różniące się polityczną historią i zwyczajami zamieszkujących je społeczności. Są to: były zabór rosyjski, były zabór austriacki, były zabór pruski oraz ziemie zachodnie i północne. Jednak z badań przeprowadzonych przez Polskie Generalne Studium Wyborcze (PGSW) w 1997 i 2001 r. wynika, że wpływ miejsca zamieszkania na frekwencję jest słaby. Istotna korelacja dotyczy jedynie byłego zaboru austriackiego, gdzie występuje wyższa frekwencja wyborcza oraz byłego zaboru rosyjskiego, gdzie obserwujemy wysoka absencję. Zamieszkanie w dwóch pozostałych regionach nie wpływa w sposób istotny statystycznie na udział w wyborach. Stałe zróżnicowanie frekwencji w regionach tłumaczyć można innymi zmiennymi, takimi jak wiek, stopień bezrobocia czy religijność, nierównomiernie występującymi w poszczególnych częściach kraju ${ }^{13}$.

Przedstawiony katalog determinantów aktywności politycznej wyborców jest bardzo szeroki. Na udział w głosowaniu powszechnym wpływać może: dokonanie przez wyborcę bilansu potencjalnych zysków i strat, wynikających z oddania głosu; specyfika sytuacji przedwyborczej oraz rodzaj wyborów; dostępność do informacji na temat związku polityki rządu i decyzji politycznych z interesami jednostki lub grupy; brak lub niewielka ilość krzyżujących się nacisków; presja społeczna mobilizująca do oddania głosu oraz zmienne demograficzne, takie jak płeć, wiek czy miejsce zamieszkania. Wskazane przyczyny wysokiej lub niskiej frekwencji wyborczej moga być stosowane zarówno do wyjaśniania przeszłych jak i przyszłych wydarzeń. Nie jest to jednak katalog zamknięty. Schematyczne i powierzchowne interpretowanie owych determinantów może wpływać na nieprecyzyjność prognozowania.

Z powyższej analizy wyłania się profil osobowościowy wyborcy, który może przyjać jedną $z$ trzech postaw ${ }^{14}$ :

- zwykle uczestniczy w wyborach,

\footnotetext{
13 M. Cześnik, Partycypacja wyborcza w Polsce 1991-2001, w: System partyjny $i$ zachowanie wyborcze. Dekada polskich doświadczeń, pod red. Radosława Markowskiego, ISP PAN, Warszawa 2002, s. 67-69.

${ }^{14}$ K. Skarżyńska, dz. cyt., s. 49-50.
} 
- czasem uczestniczy a czasem nie, co zależy od sytuacji wyborczej i opisanych wyżej czynników,

- nie uczestniczy w wyborach (permanent non-voter).

Postawę trzecią przyjmuje zazwyczaj nie więcej niż $10 \%$ uprawnionych do głosowania. Co ciekawe, odsetek obywateli permanentnie nie głosujących nie wzrasta a jednocześnie frekwencja wyborcza utrzymuje się od połowy lat dziewięćdziesiątych na stosunkowo niskim poziomie. Wysoka absencja wyborcza w Polsce jest raczej regułą niż wyjątkiem, o ile tłem porównawczym uczynimy kraje europejskie, gdzie w przypadku wyborów parlamentarnych frekwencja jest rzadko niższa niż $70 \%{ }^{15}$. Tak niskie zainteresowanie obywateli życiem politycznym kraju jest niepokojące i może się okazać niebezpieczne dla demokracji. Badania CBOS z listopada 2004 r. wskazują na brak wiary Polaków w sens udziału w wyborach. Prawie 1/4 wyborców przyznała, że nie wyraża zainteresowania głosowaniem, gdyż „wybory nic nie daja”" a ich głos „nic nie zmieni”"

\section{Na kogo wyborcy głosują?}

Rozważania na temat przyczyn popularności polityków oraz udzielania poparcia kandydatom na wysokie urzędy, wyrażanego w głosowaniu, istnieja tak długo, jak długo istnieje demokracja. Poznanie źródeł preferencji wyborczych, które prowadzą do uzyskania władzy przez bardziej lub mniej demokratyczne ugrupowania, jest marzeniem zarówno polityków i ich sztabów wyborczych, jak i ogromnej rzeszy socjologów, politologów, historyków. Analizą przyczyn zachowań politycznych elektoratu zajmuje się psefologia - odrębna dziedzina wiedzy, powstała w procesie gromadzenia wyników badań dotyczacych zachowań wyborczych ${ }^{17}$. W celu znalezienia czynników determinujących stabilność i zmienność decyzji wyborczych posługuje się ona głównie metodami ilościowymi, takimi jak badania sondażowe. Podobnie jak w przypadku frekwencji, także w odniesieniu do preferencji wyborczych istnieje wiele modeli teoretycznych próbujących wyjaśnić przyczyny zjawiska.

$15 \mathrm{~J}$. Raciborski, Absencja wyborcza: obraz i uwarunkowania zjawiska, w: Naród, władza, społeczeństwo, pod red. Aleksandry Jasińskiej-Kani, Jacka Raciborskiego, Scholar, Warszawa 1996, s. 211.

16 Nie wierza politykom' - prayczyny deklarowanej absencji wyborczej, CBOS, Warszawa 2004, http:/ / www.zigzag.pl/cbos/details.asp?q=a1\&id=3223, 14.11.2006.

17 W. Cwalina, A. Falkowski, Marketing polityczny. Perspektywa psychologiczna, GWP, Gdańsk 2005, s. 56. 
Pierwszych znaczących analiz aktywności politycznej wyborców dokonali P. Lazarfeld, B. Berelson i H. Gaudet w latach 40. XX w. Prezentowali oni socjologiczne podejście do zachowań wyborczych, zgodnie z którym preferencje wyborców determinowane są przez przynależność do wspólnot społecznych, takich jak grupa religijna, etniczna, społeczna czy zawodowa. Akt głosowania postrzegany jest jako zachowanie kolektywne, o czym świadczy duża zgodność preferencji w rodzinach, podobne decyzje wśród przyjaciół i silny wpływ liderów opinii w grupach. Za podstawowe determinanty kształtujace postawy wyborców uznano zmienne demograficzne i geograficzne, takie jak przynależność klasowa, płeć, wiek, pochodzenie etniczne, religijność, kontekst społeczny. Na podstawie badań sondażowych (głównie typu exit polls) i przeprowadzanych analiz sztaby wyborcze są w stanie określić szanse kandydatów w poszczególnych przedziałach ${ }^{18}$. Model socjologiczny nie jest jednak pozbawiony niedoskonałości, gdyż kładąc nacisk na stabilność zachowań wyborczych, nie jest w stanie wyjaśnić zmian preferencji. Schemat głosowania klasowego, zgodnie z którym klasa robotnicza popiera lewicę natomiast klasa średnia prawicę zanika prawie we wszystkich systemach partyjnych. Z badań dotyczących polskich wyborów prezydenckich w 1995 r., przeprowadzonych przez R. Markowskiego i J. Raciborskiego wynika, że dla wyborców ważniejsze od stratyfikacji społecznej były względy symboliczno-ideologiczne (członkostwo w PZPR czy Solidarności). W wyborach parlamentarnych i prezydenckich w Polsce w 2005 roku podział postkomuniści vs postsolidarnościowcy, czy lewica kontra prawica ustapił miejsca nowemu - Polska solidarna vs Polska liberalna.

Lazarfeld, Berelson Gaudet wyjaśniali zachowania wyborcze także w kategorii zachowań konsumenckich ${ }^{19}$. Uważali oni, iż wyborcy podejmuja decyzje na podstawie kampanii wyborczej. Sformułowana przez nich teza o znaczącym, lecz ograniczonym wpływie mediów na postawy odbiorców przeczyła popularnej wówczas teorii "magicznego

18 W 1995 r. w grupie kobiet między 40 a 49 rokiem życia, z wykształceniem średnim, pracujących w biurze, zamieszkałych w miastach do 100000 mieszkańców, w regionie Wielkopolski, prawdopodobieństwo oddania głosu na Aleksandra Kwaśniewskiego wynosiło 64,6 \%. Zmiana tylko jednego z wymienionych wskaźników - wieku powodowała spadek poparcia o 4,6 \%. Z kolei w przypadku głosowania na Lecha Wałęsę najistotniejszą zmienną okazał się region zamieszkania - w Małopolsce było to poparcie ponad $63 \%$, natomiast w regionie północno-wschodnim (przy takich samych pozostałych zmiennych) już o $12 \%$ mniej. Por. Tamże, s. 57-62.

${ }^{19} \mathrm{~K}$. Giereło, Telewizja jako istotny czynnik ksztattujacy role aktorów politycznych oraz widzón, w: Marketing polityczny w poszukiwaniu strategii wyborczego sukcesu, pod red. Marka Jelińskiego, Dom Wydawniczy Duet, Toruń 2004, s. 222-223. 
pocisku", w myśl której media traktowane były jak pocisk, który wystrzelony w odpowiednim kierunku, gdy dotrze do właściwych oczu i uszu wywoła zamierzony skutek. Naukowcy doszli do wniosku, iź środki masowego przekazu rzadko wywołują radykalną zmianę preferencji odbiorców. Jednak już w latach 70. ponownie zwrócono uwagę na wpływ mediów na długoterminową zmianę postaw. Grupa badaczy złożona z dziennikarzy, pracowników agencji reklamowych i ogłoszeniodawców, sformułowała teorię o dużym wpływie mediów nie tylko na postawy jednostkowe, ale przede wszystkim na świadomość społeczną, także w kontekście preferencji politycznych. Współcześnie popularne jest podejście konstruktywistyczne (model negocjowalnego wpływu mediów), według którego to odbiorcy wybierają interesujące ich przekazy lub treści a na ich podstawie konstruują wizję rzeczywistości. Istotna jest zarówno siła mediów jak i odbiorców na bazie stałej negocjacji znaczeń. Nie należy więc przeceniać wpływu mediów na preferencje wyborców, gdyż znaczna ich część podejmuje decyzje na kogo głosować na długo przed rozpoczęciem kampanii wyborczej. Wysiłki sztabów maja na celu przekonanie grupy wyborców niezdecydowanych, gdyż twardy elektorat jest w niewielkim stopniu podatny na perswazje i rzadko zmienia decyzję dotycząca głosowania. Co ciekawe, z badań przeprowadzonych w Polsce w 2001 r. wynika, iż ludzie sądzą, że telewizja nie wpływa na ich decyzje wyborcze, natomiast wpływa na decyzje innych, przede wszystkim przeciwników politycznych. Przekonanie o wpływie telewizji na poglądy innych jest tym silniejsze, im bardziej dana osoba jest zaangażowana w politykę, przekaz uważany za szkodliwy społecznie a intencja nadawcy oceniana negatywnie ${ }^{20}$.

Wiedzy na temat preferencji wyborczych dostarcza też opisany już model racjonalnego wyborcy Downsa. Wyborca dokonując rachunku zysków i strat zarówno zastanawia się czy udać się do urny wyborczej, jak i na kogo oddać głos. Analizuje, która z dostępnych na rynku politycznym ofert jest mu najbliższa, w najszerszy sposób spełnia jego oczekiwania, maksymalizuje zysk. Jeżeli wyborca podejmując decyzję na kogo głosować, bierze pod uwage przede wszystkim przesłanki ekonomiczne - własną sytuację finansową lub stan gospodarki krajowej, wówczas mamy do czynienia z głosowaniem ekonomicznym (economic voting), zwanym też retrospektywnym. Upraszczając, opiera się ono na założeniu sformułowanym przez M. S. Lewisa-Becka, iż „im lepiej

${ }^{20}$ B. Wojciszke, Człowiek wśród ludzi. Zarys psychologii społecznej, Scholar, Warszawa 2002, s. $200-201$. 
postrzegana jest kondycja i dynamika gospodarki, tym bardziej elektorat skłonny jest głosować na partię rządzącą. W przeciwnym wypadku rośnie jego skłonność głosowania na partię opozycyjną" ${ }^{21}$. Wyborcy przed udaniem się do lokali wyborczych podsumowuja, jak im się żyło w okresie od ostatnich wyborów. Wybory sa tu traktowane jak proces swoistego nagradzania lub, co występuje częściej, karania sprawujących władzę.

Za B. Markusem wyróżnić można dwie odmiany głosowania retrospektywnego: głosowanie oparte na portfelu (pocketbook voting), gdy wyborcy analizuja przede wszystkim własną sytuację finansową oraz głosowanie zorientowane społecznie (sociotropic voting), gdy analizowany jest stan gospodarki krajowej. Z badań przeprowadzonych w 17 krajach w latach 1960-1987 wynika, że w państwach o słabo rozbudowanym systemie opieki społecznej (np. USA, Kanada, Australia, Hiszpania, Wielka Brytania, Japonia) przeważa głosowanie socjotropiczne, natomiast tam, gdzie mamy do czynienia ze zinstytucjonalizowanym systemem opieki (np. Dania, Szwecja, Niemcy, Włochy) przeważa głosowanie portfelowe ${ }^{22}$.

Nie należy jednak ograniczać motywów głosowania do czynników ekonomicznych, gdyż pomijając rolę emocji, sprowadzamy jednostkę do poziomu procesora komputera. Stosunek emocjonalny do kandydata w sposób istotny koreluje z zamiarem głosowania na niego, czego dowodza m.in. badania przeprowadzone w trakcie rywalizacji pomiędzy G. Bushem a M. Dukakisem w 1988 r. w USA, czy podczas wyborów prezydenckich w Polsce w roku 1995. Z przytoczonych analiz wynika, iż zdarza się, że „ludzie bardziej głosuja swoimi sercami niż umysłami" "23. Konieczne jest więc uwzględnienie czynnika ludzkiego psychiki, doświadczenia i przeżyć wewnętrznych.

W Polsce głosowanie ekonomiczne przybiera specyficzną formę. Po pierwsze dlatego, że linia podziału - głosowanie oparte na portfelu $v$ s głosowanie zorientowane społecznie jest niewyraźna. Po drugie, według K. Jasiewicza, jeśli chcemy w Polsce zgadnać, jak ktoś głosował w ostatnich wyborach lub jak zagłosuje w następnych, powinniśmy zapytać go, nie o zawód, wykształcenie czy grubość portfela, lecz o to, jak często

21 M. S. Lewis-Beck, Comparative Economic Voting: Britain, France, Germany, Italy, „American Journal of Political Science”, 1986, nr 30.

22 W. Cwalina, A. Falkowski, dz. cyt., s. 71-72.

${ }^{23}$ E. Aronson, T. D. Wilson, R. M. Akert, Psychologia społecæna. Serce i umyst, Zysk i S-ka, Poznań 1997, s. 329. 
odmawia różaniec ${ }^{24}$. W krótkiej historii polskiej demokracji nie zdarzyło się jeszcze nigdy, aby partia objęła władzę w dwóch kolejnych wyborach. Tłumaczenie takiego stanu rzeczy tezą Lewisa-Becka byłoby mijającym się z prawdą uproszczeniem. Stosunek wyborców do następujących po sobie rządów nie może być traktowany jako odwrotnie proporcjonalny. Układ partyjny w Polsce jest nadal niestabilny, wciąż pojawiają się na scenie politycznej nowe ugrupowania lub rozpadają już istniejące. W związku z tym wyborca nie jest w stanie w sposób jednoznaczny przypisać odpowiedzialności za ostatni okres rządów poszczególnym partiom (np. w wyborach parlamentarnych w 2001 r. po rozpadzie AWS $)^{25}$. Teoria głosowania ekonomicznego lepiej sprawdza się w przypadku systemów dwupartyjnych.

Podstawowym zarzutem wysuwanym pod adresem teorii racjonalnego wyboru oraz teorii głosowania ekonomicznego jest brak odpowiedzi na pytanie, w jaki sposób wyborca weryfikuje i hierarchizuje docierające do niego informacje. Krytycy rational voting (m.in. D. Kahneman, A. Tversky, I. Page, J. H. Kuklinski) twierdzą, iż człowiek, analizując otaczająca go rzeczywistość, kieruje się zasadą ekonomizacji myślenia, nie dokonuje drobiazgowych analiz, koncentruje się na specyficznych aspektach docierających do niego informacji. Posługiwanie się skrótami poznawczymi, zasadami wnioskowania (heurystykami) występuje najczęściej gdy czujemy się niepewnie w danej sytuacji. Szczegółowe i poprzedzone głęboką analiza decyzje wyborców, w myśl krytyków modelu Downsa, sa raczej wyjątkiem niż regułą a w pełni racjonalny wyborca nie istnieje $\mathrm{e}^{26}$.

Determinanty preferencji wyborczych tłumaczone są także za pomoca modeli kierunkowych, będących pochodnymi teorii racjonalnego wyboru. Zakłada się w nich, że wyborca zagłosuje nie na partię najbliższa sobie programowo lecz na tą, której kierunek polityki najbardziej mu odpowiada. Twórcami tej szkoły interpretacji zachowań wyborczych są S. E. Mcdonalds i G. Rabinowitz. Według ich koncepcji partia, która zapewni wyborcy maksymalną użyteczność wcale nie musi być tą najbliższą programowo. W modelu kierunkowym preferencje wyborcze determinowane są przez wagę (kierunek) i intensywność

${ }^{24}$ K. Jasiewicz, Portfel cay różaniec? W zory zachowań wyborczych Polaków w latach 1995-2001, w: System partyjny i zachowanie wyborcze, dz. cyt., s. 98.

25 P. Grzelak, Głosowanie ekonomiczne w Polsce, w: System partyjny $i$ zachowanie wyborcze, dz. cyt., s. 236-239.

${ }^{26}$ Jeden z teoretyków psefologii - J. J. Mondak - wyróżnił siedem reguł wnioskowania: lubienia, równoważenia, odbierania sygnałów, zasługiwania, dostępności, oparta na afekcie i stereotypowa. Por. W. Cwalina, A. Falkowski, dz. cyt., s. 75. 
proponowanych zmian. Dla partii korzystne jest uwzględnienie społecznie ważnych kwestii, takich jak bezrobocie, aborcja czy lustracja i zaproponowanie takich rozwiązań, jakie zadowola największą liczbę odbiorców. Jeżeli główną determinantą preferencji wyborczych jest podejście kandydata/partii do owych istotnych kwestii społecznopolitycznych, wówczas mamy do czynienia z głosowaniem tematycznym (issue voting) ${ }^{27}$. Aby głosowanie można było nazwać tematycznym podnoszone kwestie muszą być identyfikowane jako istotne dla potencjalnych wyborców a polityk reprezentujący daną kwestię musi być z nią łatwo utożsamiany. Jeżeli natomiast rywalizujące ze sobą partie prezentuja pokrewny kierunek polityki w danej kwestii, wyborcy szukaja zmiennych, które ich różnicuja. Sytuacja taka miała miejsce np. w Stanach Zjednoczonych w 1968 r., gdy kandydaci na urząd prezydenta wypowiadali się podobnie na temat wojny w Wietnamie. Kwestia ta stała się więc nieistotna i nie brano jej pod uwagę udzielając poparcia wyborczego $^{28}$. W przypadku braku zróżnicowania kandydatów, zwłaszcza jeżeli chodzi o decydująca fazę wyborów prezydenckich, zmiennymi decydującymi o oddaniu głosu na danego kandydata moga okazać się jego wzrost, uroda czy atrakcyjność żony. Wielu badaczy twierdzi, że R. Nixon przegrał z J. F. Kennedym wyścig o fotel prezydenta USA, gdyż w trakcie decydującej debaty telewizyjnej był mniej starannie ogolony niż kontrkandydat. Potwierdzeniem wpływu wyglądu zewnętrznego na kształtowanie opinii o jednostce są badania przeprowadzone przez Lefkowitza w USA. Gdy młody mężczyzna, ubrany w garnitur i krawat przekraczał jezdnie na czerwonym świetle podążało za nim trzyipółkrotnie więcej przechodniów, niż gdy przekraczał jezdnie ubrany we flanelową koszulę i spodnie ${ }^{29}$. Nie należy jednak przeceniać wpływu wyglądu zewnętrznego na ocenę kandydatów, o czym przekonał się sztab wyborczy M. Krzaklewskiego w kampanii prezydenckiej w 2000 r. W stosunku do wyborów prezydenckich 2005 można z dużą dozą pewności stwierdzić, iż wyżej wymienione niemerytoryczne czynniki nie miały wpływu na wybór L. Kaczyńskiego na urząd Prezydenta.

Od kilkudziesięciu lat obserwuje się wzrost znaczenia głosowania tematycznego zarówno w Stanach Zjednoczonych jak i w Europie. Także w przypadku Polski badania przeprowadzone przez K. Skarżyńską, K. Korzeniowskiego i R. Markowskiego już w 1995 roku

\footnotetext{
${ }^{27}$ K. Korzeniowski, dz. cyt., s. 247.

${ }^{28}$ K. Skarżyńska, dz. cyt., s. 48.

${ }^{29}$ K. Korzeniowski, dz. cyt., s. 251.
} 
wskazuja na wpływ poruszanych w kampanii wyborczej kwestii społeczno-politycznych zarówno na frekwencję jak i preferencje wyborców ${ }^{30}$. Wynikać to może ze wzrostu świadomości politycznej obywateli, związanej z rozwojem Internetu i coraz łatwiejszym dostępem do informacji. W wyborach parlamentarnych w Polsce w 2005 r. istotnymi kwestiami okazały się m.in. polityka społeczna i system podatkowy oraz związany z nimi podział na Polskę liberalną i solidarną.

\section{Uwagi końcowe}

Przedstawiona charakterystyka determinantów zachowań wyborczych prowadzi do wniosku, iż jednoznaczna odpowiedź na pytanie: „Dlaczego i na kogo wyborcy głosują?” - jest niezwykle trudna. Przytoczone modele teoretyczne, stanowiące fundament niniejszych rozważań, w dużej mierze tłumaczą motywy zachowań wyborczych, jednak przy każdej odpowiedzi pojawia się kilka kolejnych pytań. Trudności w analizie wynikaja z faktu, iż teoria nie zawsze pokrywa się z rzeczywistością. Podstawowym błędem na gruncie teoretycznym wydaje się być nadmierna generalizacja, pomijająca jednostkowość zachowania, jakim jest akt głosowania. Wysiłek podjęty w celu zrozumienia przyczyn danego poziomu frekwencji oraz preferencji elektoratu musi zawsze uwzględniać specyfikę państwa czy regionu, czynniki demograficzne i kulturowe oraz czasową niestabilność zachowań wyborczych.

Rozważania na temat zachowań wyborczych stanowią bardzo istotną i wciąż rozwijająca się gałąz takich dziedzin jak marketing polityczny, psychologia, socjologia czy teoria polityki. Umiejętne prognozowanie preferencji wyborczych nie zawsze jednak korzystnie wpływa na stan demokracji i pozycję obywateli. Obserwowany od połowy XX w. rozwój marketingu politycznego, profesjonalizacja kampanii wyborczych i mediatyzacja polityki wpływaja na upodmiotowienie wyborcy i sprowadzenie go do roli klienta na rynku politycznym. Demokrację można natomiast, za R. Dahrendorfem, nazwać „sondażową", gdyż o przebiegu kampanii wyborczej oraz wizerunkach kandydatów decydują wyniki sondaży, informujące specjalistów ze sztabów wyborczych, czego wyborcy oczekuja, co chcieliby usłyszeć i zobaczyć. Współczesne kampanie coraz mniej wspólnego maja z uczciwą rywalizacja oraz chęcia przeprowadzenia

30 Por. Tenże, O frekwencii wyborczej w roku 1995. Skad ten rekord?, w: Wybory preaydenckie 1995, pod red. Stanisława Gebethnera, Elipsa, Warszawa 1998; R. Markowski, Kwestie publiczne w modelu determinacji decyzji wyborczych, w: Wybory prezydenckie 1995, dz. cyt. 
słusznych reform. Warto też zastanowić się nad skutkami aktywności i bierności politycznej wyborców. Małe zainteresowanie wyborami w państwie demokratycznym może oznaczać, iż społecznie i ekonomicznie nieuprzywilejowane grupy maja zbyt mała reprezentację w rządzie. Zdaniem V. O Key’a brak partycypacji politycznej oznacza nieistnienie społeczeństwa obywatelskiego, czego konsekwencją jest brak lojalności wobec całego systemu. Alternatywna szkoła myślenia, reprezentowana przez F. Wilsona, H. Tingstena i D. Riesmana, preferuje niską frekwencję wyborczą, gdyż jest to, ich zdaniem, dowód ogólnego zadowolenia elektoratu z istniejącego stanu rzeczy. W. B. Munro już w 1928 r. ostrzegał, iż zwiększona partycypacja może zagrażać demokracji, gdyż „niebranie udziału w wyborach dotyczyło głównie najmniej wykształconej części elektoratu" ${ }^{31}$. Warto podkreślić, że ci, którzy zazwyczaj nie głosuja, posiadaja podobne cechy, co jednostki podatne na wpływy haseł populistycznych i antysystemowych. Trudno jednak jednoznacznie rozstrzygnać spór co lepsze dla sprawnego funkcjonowania demokracji - wysoka czy niska frekwencja wyborcza? Uprawniona wydaje się być teza, iż brak zainteresowania życiem politycznym i losami kraju ze strony społeczeństwa nie wróży dobrze demokracji. Sposobem rozwiązania problemu wysokiej absencji wyborczej może być próba aktywizacji społeczeństwa. Z badań bowiem wynika, że osoby, które widzą dla siebie szanse w systemie, możliwość rozwoju i polepszenia własnej sytuacji materialnej częściej uczestniczą w wyborach. Proces aktywizacji powinien być wolny od jakichkolwiek form przymusu. Wyjątek stanowi tu sytuacja istnienia regulacji prawnych, obligujących obywateli do głosowania. Zdaniem J. Habermasa, dla współczesnej demokracji niezbędne jest ożywienie sfery publicznej oraz społecznego dialogu, wpisujących się w model uczestniczącej kultury politycznej ${ }^{32}$.

\footnotetext{
31 S. M Lipset, dz. cyt., s. 231-234.

${ }^{32} \mathrm{~J}$. Habermas, Obywatelstwo a to ̇̇samosí narodowa. Roz̧ważania nad praysz̨ościa Europy, IFiS PAN, Warszawa 1993, s. 14.
} 